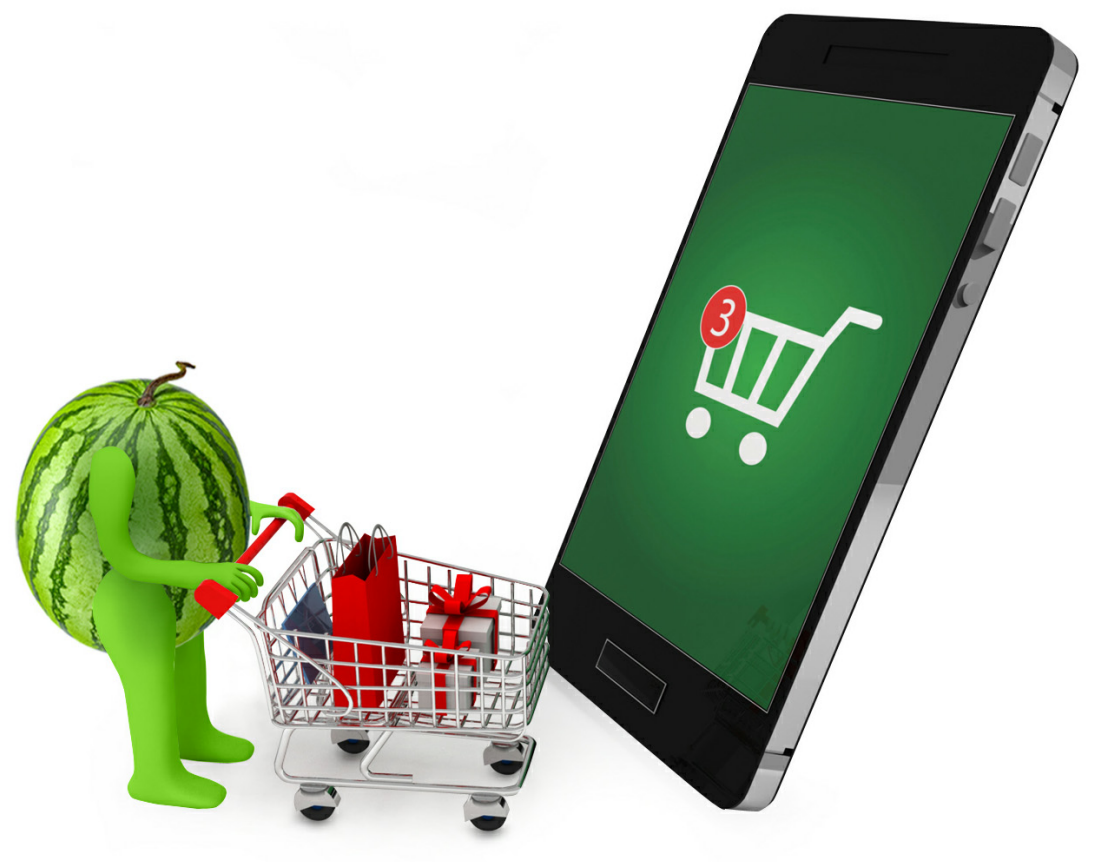

UNDERSTANDING FACTORS INFLUENCING CONSUMERS ONLINE PURCHASE INTENTION VIA MOBILE APP: PERCEIVED EASE OF USE, PERCEIVED USEFULNESS, SYSTEM QUALITY, INFORMATION QUALITY, AND SERVICE QUALITY 


\title{
UNDERSTANDING FACTORS INFLUENCING CONSUMERS ONLINE PURCHASE INTENTION VIA MOBILE APP: PERCEIVED EASE OF USE, PERCEIVED USEFULNESS, SYSTEM QUALITY, INFORMATION QUALITY, AND SERVICE QUALITY
}

\author{
Markun Hanjaya, S.T. \\ Business Management Program, Management Department, BINUS Business School Master Program, \\ Bina Nusantara University, Jakarta, Indonesia 11480 \\ markun.hanjaya@gmail.com
}

\section{Kenny, S.Kom.}

Business Management Program, Management Department, BINUS Business School Master Program, Bina Nusantara University, Jakarta, Indonesia 11480

kennywijaya92@gmail.com

\section{Freddy Gunawan, S.S., S.E.}

Business Management Program, Management Department, BINUS Business School Master Program, Bina Nusantara University, Jakarta, Indonesia 11480

freddy.gunawan.network@gmail.com

DOI: 10.2478/minib-2019-0035

\section{Summary}

The development of technology has been significantly given the implication towards consumer's behaviour in having the online purchase intention via mobile app that has been developed by the e-commerce company to serve better and deliver a better service to the consumers; especially when internet has connected people through their smartphones. The insignificant growth in doing the online purchase via mobile app which does not go along with the growth of internet mobile users in Indonesia and Singapore will deliver this study in order to evaluate and validate the implication of ease of use, usefulness, system quality, information quality, and service quality towards consumer's behaviour in having the online purchase intention via mobile app. Data was gathered with survey by spreading 100 questionnaires randomly to the respondents who had the experience in doing the online purchase via mobile app in the last 6 months in Indonesia and Singapore. The methodology in doing this study is the quantitative approach by considering the connection amongst the independent variables and the dependent variables. This research found that usefulness and information quality significantly affect the online purchase intention through mobile app in Indonesia while in Singapore ease of use, usefulness, and service quality significantly affect the online purchase intention through mobile app.

Keywords: Ease of Use, Usefulness, System Quality, Information Quality, Service Quality, Consumer's Behaviour, Online Purchase Intention, Mobile App 



\section{Introduction}

Nowadays, the purchasing behaviour from the consumers in the retailing industry has changed and it has been considered as a noteworthy directional change from physical stores buying behaviour to web based acquiring behaviour. This situation goes along with the changing trend of consumer behaviour from using the desktops into smartphones. Southeast Asia is believed as the fastest growing e-commerce in terms of sales revenue and predicted will be exceeding $\$ 25 \mathrm{~B}$ in 2020 and $88.1 \mathrm{~B}$ in 2025 (Frost \& Sullivan, 2016 \& Google, 2017) and the contribution came from the six largest market in Southeast Asia: Indonesia, Thailand, Singapore, Malaysia, Vietnam, and Philippines (eMarketer, 2016 \& Statista, 2016). In the latest finding from Frost \& Sullivan (2018), quarter-on-quarter growth in Southeast Asia was 28.5\% which surpassed \$6B revenue in Q4 2017 with Indonesia still the largest market contributed one third of the Southeast Asia market with 25\% quarteron-quarter growth in Q4 2017.

In addition, Southeast Asia is a mobile-first economy with more than $90 \%$ internet users are on smartphone and spending an average 3.6 hours per day on mobile internet, more than any other region in the world (Google, 2017). Again, Indonesia is the leading market with $87 \%$ of mobile traffic followed by Thailand, Philippines, Singapore, Malaysia and Vietnam respectively (iPrice, $2017 \&$ WeAreSocial, 2018). However, with more than $90 \%$ users are on the smartphone and stated as mobile-first economy, it is not followed by the significant growth of online purchase via mobile app. Majority of the customers still use website to search and make their purchase, where there is an increasing trend to use mobile apps (Frost \& Sullivan, 2018). Google (2015) also found similar result earlier where this situation happened because most users still use mobile as the first step in order to find and compare the products that they will buy, which then they will purchase the desired product in-store or via desktop or laptop if they want to buy the desired product online. This trend can be seen in the six largest market in Southeast Asia where the conversion rate on desktop in average 2.5-3x higher than mobile (iPrice, 2017). WeAreSocial (2018) have gathered the data to show the comparison between Indonesia market and Singapore market in regards the purchase intention. Based on the data, total population in Indonesia is bigger population $265.4 \mathrm{M}$ than Singapore 5.75M. This number is resulting Indonesia 
to have around $132.7 \mathrm{M}$ with $50 \%$ penetration of internet users and $4.83 \mathrm{M}$ with $83 \%$ penetration of internet users. Total of unique mobile users of Indonesia has lesser penetration compared to Singapore (67\% to $82 \%$ ) which is in line with the active mobile internet users in Indonesia and Singapore. Even though the web traffic by using the laptop and desktop is lower than the web traffic by using the mobile phones in both countries, it does not show any significant growth in doing the online purchase via mobile. With the percentage of $31 \%$, Indonesia has lower online purchase made via mobile app that being developed by the company compared to Singapore which is $39 \%$. Based on the data from iPrice (2017), it has shown that the conversion rate in both countries are having bigger online purchase made via desktop rather than mobile app with a significant average order value as well in both countries. Data shows that Indonesia has the overall country index score for 52.71 out of 100 while Singapore has 83.42 out of 100 . The mobile network infrastructure does seem to be higher in Singapore (81.14) compared to Indonesia (41.39). Data delivers as well the conclusion data for the readiness of consumers which is Singapore (82.47) is higher than Indonesia (69.09).

Indonesia and Singapore are different each other in regards about the facilities and infrastructures that cause the different readiness from the consumers in utilizing the internet to do the online purchase. By becoming the emerging country, Singapore has the competitive advantage in the aspects of consumers readiness. The readiness from the consumers in both countries is showing pretty significant difference in percentage $69.09 \%$ and $82.47 \%$ because of the understanding how to use mobile internet or appreciate how the mobile internet can benefit them is different. Therefore, it is very important and necessary to consider the level of skills and education background of a country, as well as the degree of education, finance and in the labour market.

However, the facts say contrastly on the conversion rate that happens in Singapore which is lower than Indonesia. The conversion rate from Indonesia is higher than Singapore might become the sign that Indonesia is the potential market to grow the e-commerce business in Southeast Asia. By seeing the slow growth of online purchases through mobile app in Indonesia and Singapore, this is a big challenge and can affect the development of the company especially if the company focuses on mobile technology. 
Table 1. Digital and Mobile in Indonesia and Singapore

\begin{tabular}{|c|c|c|}
\hline Indicators & Indonesia & Singapore \\
\hline Total Population & $265,4 \mathrm{M}$ & $5,75 \mathrm{M}$ \\
\hline Internet Users & 132, M - Penetration $50 \%$ & $4.83 \mathrm{M}$ - Penetration $83 \%$ \\
\hline Unique Mobile Users & $177.9 \mathrm{M}$ - Penetration $67 \%$ & $4.71 \mathrm{M}$ - Penetration $82 \%$ \\
\hline Active Mobile Internet Users & $124.8 \mathrm{M}$ - Penetration $47 \%$ & $4.58 \mathrm{M}$ - Penetration $80 \%$ \\
\hline Web Traffic Laptop \& Desktop & $26 \%-\mathrm{YoY}-8 \%$ & $20 \%-\mathrm{YoY}-60 \%$ \\
\hline Web Traffic Mobile Phones & $72 \%-\mathrm{YoY}+5 \%$ & $78 \%-\mathrm{YoY}+75 \%$ \\
\hline Do Online Purchase via Laptop or Desktop & $31 \%$ & $39 \%$ \\
\hline Do Online Purchase via Mobile Device & $31 \%$ & $39 \%$ \\
\hline Conversion Rate* (Desktop) & $3.3 \mathrm{x}$ & $3 \mathrm{x}$ \\
\hline Conversion Rate* (Mobile) & $1.3 \mathrm{x}$ & $0.9 x$ \\
\hline Total Annual Sales Revenue & $\$ 7,056$ Billion & \$ 3.326 Billion \\
\hline Average Order Value (Desktop) & $\$ 42$ & $\$ 96$ \\
\hline Average Order Value (Mobile) & $\$ 35$ & $\$ 82$ \\
\hline
\end{tabular}

Mobile Connectivity Index

Overall Country Index Score

Mobile Network Infrastructure

Consumer Readiness
52.71 out of 100

41.39 out of 100

69.09 out of 100
83.42 out of 100

81.14 out of 100

82.47 out of 100

Source: iPrice, 2017 i WeAreSocial, 2018.

* Using the average mobile conversion rate in SEA as reference (1x).

* Conversion rate is the \% of visits that turn into a product purchase.

It is suspected that mobile app does not meet the requirements from the consumers in doing the online purchase. Therefore, this study will find out and compare what are the factors that might influence the consumer's behaviour in having online purchase intention via mobile app in Indonesia as developing market and Singapore as emerging market. In general, someone's intention in doing online purchase is influenced by several factors such as trust 
and risk, perceived convenience, and the benefits that being provided (Dachyar dan Banjarnahor, 2017; Ling, Daud, Piew, Keoy, dan Hassan, 2011; Heijden, Verhagen, dan Creemers, 2003). However, in doing the online purchase through mobile, there are several different factors such as product features, brand reputation, social influence, system quality, information and services that being offered (Rahim, Safin, Kheng, Abas, Ali, 2015; Chen, 2013).

\section{Research Problem (Problem Statement)}

Southeast Asia eCommerce is a mobile-first economy, upsurging all the western economies when it comes to the importance aspect or indicator of Mobile commerce in the traffic which generated by each eCommerce operator. In Southeast Asia's eCommerce, the rise of mobile appears so aggressive and unstoppable. The population of mobile has grown on average $19 \%$, and growing for $72 \%$ of the overall eCommerce web traffic in the past 12 months. Indonesia is leading the pack, which now has an astonishing $87 \%$ share of mobile traffic.

In none of Southeast Asia's country desktop traffic accounts for more than $30 \%$ of web traffic. Based on the background of the problems that have been compiled, there is a significant growth of mobile usage through mobile and laptop or desktop in accessing internet in Indonesia which has reached to $87 \%$.

Conversely, the significant growth in mobile usage through smartphone gives different story to the growth of online purchase intention via mobile app. By having this gap, it will become the problem ' to be examined through this study which will accordingly to find out the factors that affecting the consumer's behaviour which ultimately will decide to buy the desired products online through mobile app 


\section{Research Objectives}

The main objective of this research is to distinguish the significant influence of ease of use, usefulness, system quality, information quality, and service quality towards consumer's behaviour in having online purchase intention via mobile app in Indonesia and Singapore.

\section{Research Questions}

The questions that need to be analyzed and revealed in this study are:

1. Why the growth of online purchase via mobile app is not reflecting the same growth just like the growth of internet mobile usage in Indonesia and Singapore?

2. What is the significant factors that could influence the online purchase intention via mobile app in Indonesia and Singapore?

3. What are the aspects that being influenced by those factors and what are the implication towards the online purchase intention via mobile app?

\section{Literature review}

Intention is a motivation that can affect a person in forming certain desired behaviour and can be used to see how much desires and efforts of someone in order to achieve the behaviour (Ajzen, 1991). According to Pavlou (2003), online purchase intention aim can be characterized as a circumstance where a buyer is eager and expecting to make online exchanges which are comprised of three stages: information retrieval, information transfer and product purchase. According to Shah et al. (2012) purchase intention is a decision based on a person's reason to buy a brand of their choice. This research was conducted to study the 
effect of ease of use, usefulness, system quality, information quality, and service quality towards consumer's behaviour in having online purchase intention via mobile app. The same study says that the consumers will encounter the determining stage before doing the online purchase transactions on the products which will automatically drive the consumers to find out about the information of the desired products.

To evaluate the products that they want to buy, to make the purchase transactions, and to provide the feedbacks after the purchase process is completed from the desired products. Thus, consumers will make purchases of products after checking the products to get the right products and in accordance with the wishes of the buyers themselves.

\section{Technology Acceptance Model (TAM)}

TAM is a theory that being developed to find out how ease of use and usefulness of a system can affect someone's intention and behaviour to use the system (Davis et al., 1989). Ease of use describes how a system does not require excessive effort when being used and usefulness describes how a system can improve the performance of the system (Davis et al., 1989; Davis, 1989; McKechnie, Winklhofer and Ennew, 2006; Lee, Fiore and Kim, 2006; Chen \& Ching, 2013). In the previous study also mentioned that ease of use and usefulness have an influence on someone's intention in using a system. In the context of ecommerce, websites which are easy to use and can provide useful information will be able to increase the purchase intention (Chen \& Ching, 2013).

This is also supported by several studies which suggest that ease of use and usefulness have an effect on purchase intention in doing online shopping (Ling, Daud, Piew, Keoy, and Hassan, 2011; Heijden, Verhagen and Creemers, 2003; Gefen et al., 2003). However, online shopping on desktops and mobile provides a different experience as it has different systems, display and features which can accordingly affect the online purchases (Chen, 2013). Therefore, mobile commerce should 
be as useful and easy to use as it may affect user activity and loyalty (Ahmad \& Ibrahim, 2017). Therefore, this study will be focused on how the ease of use and usefulness can affect the purchase intention via mobile app.

\section{IS Success Model}

The IS Success Model is a theory concept used in various researches as a basic criterion in terms of evaluating and assessing the quality of information systems (Rai et al 2002). IS Success model is used to see how successful the quality of information systems created (Eom, 2013). The dimensions of information quality, system quality, and the quality of services provided will be the key factor in analyzing and estimating the quality of the information system itself. (DeLone \& McLean, 2003). D\&M IS Success model was first created by DeLone and McLean in 1992 with a model like Figure 1.

Initially DeLeon and McLean were concerned only with the quality and system quality variables. While in the development of Information System itself with the emergence of e-commerce and Online app based on mobile, the quality of service variables they need to add. Therefore, in 2003, DeLone and McLean updated their IS models by adding quality service variables rather than an information system like Figure 2.

Figure 1. Original D\&M IS Success Model (1992)

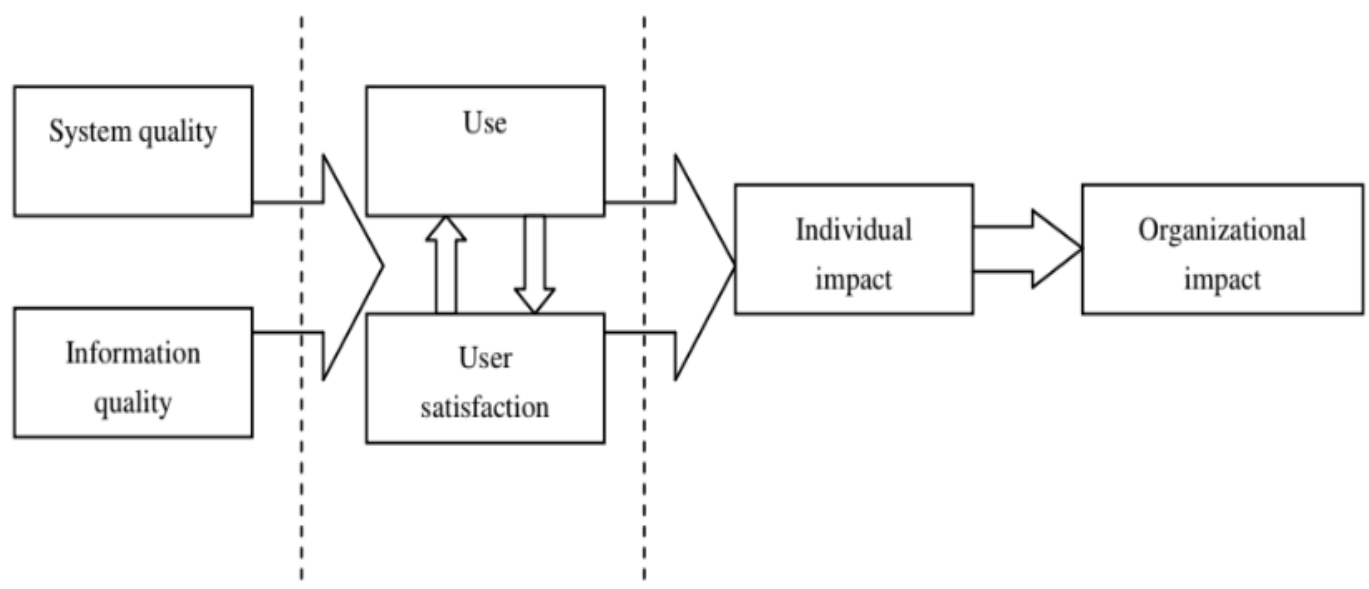


Figure 2. IS D\&M Success Model (updated) (2003)

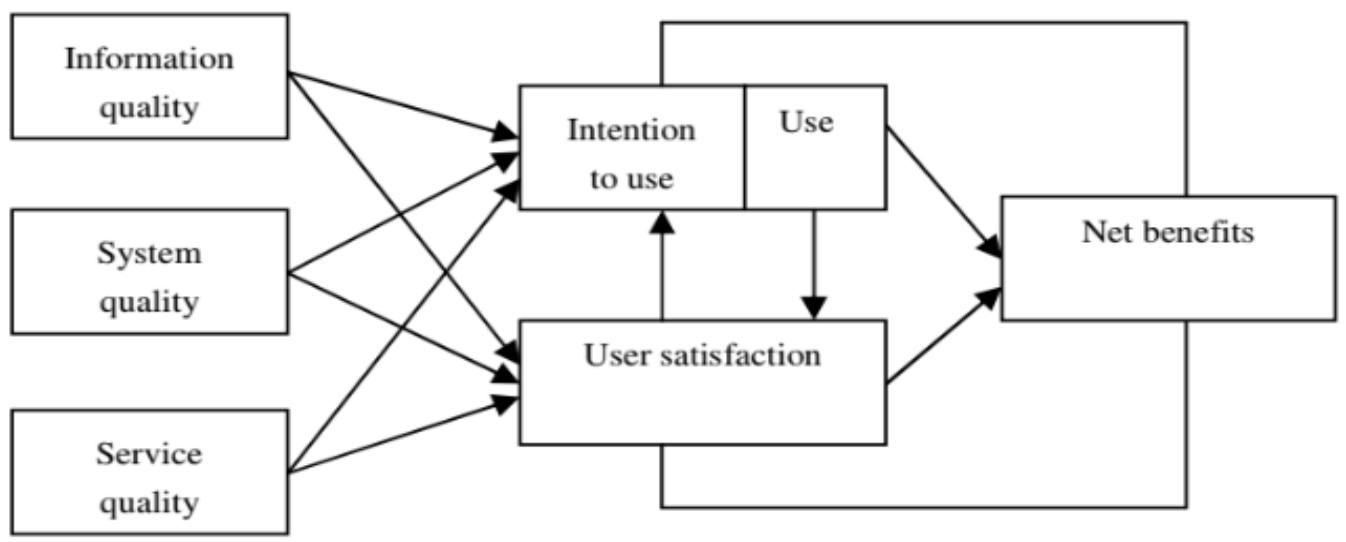

Since this model was created and carried by DeLone and McLean, this model is a central study of all research to examine the success of an information system (Pitt et al., 1995; Rai et al., 2002). This information system model can also be used and updated in the realm of the effectiveness of a website (Molla and Licker, 2001). Despite the fact that the utility and the application of the Information System success model has been successfully supported by the considerable body from past researches across wide range of information system settings, it has infrequently been used to examine the continuity of customer behaviour in the context of mobile purchase system. Research in generalize the IS success model in the context of mobile purchases is extremely needed. A mobile purchase cannot be separated from the concept of information systems, therefore the theoretical foundation that suitable is IS success model itself.

\section{Hypothesis Statements}

Mobile shopping system is technically comprises the system integration of the hardware and software along with customer-driven service. Therefore, the three dimensions of quality (system, information, and service) appear to have the potential in order to 
directly affect the purchase intention of mobile shopping system. These dimensions also reflect the unique and different aspects of IS quality and also have the unique effects on customer satisfaction (Ho, et al., 2012; Lin et al., 2011; Kim et al., 2011; Safeena and Kammani,2013).

Even though the fact of consumers are not increasingly using their smartphones to do the online shopping, by investing in mobile technology to embrace the mobile market eventually could increase the retention of existing consumers and at the same time bring new consumers. It was found that investing to develop new technology will give the company huge benefit to explore and exploit the market in a new way (Renko et al, 2009).

The acceptance of new technology will be reflected on consumers purchase intention for new products and can be easily seen among counteractive action which is customers centered (Herzenstein et al., 2007). Therefore, ease of use and usefulness of the devices are expected to deliver a solid connection to a consumer's repurchase intention. Hence, the hypotheses can be developed such as follows:

H1: Ease of Use has a significant influence towards purchase intention via mobile app.

H2: Usefulness has a significant influence towards purchase intention via mobile app.

H3: Information Quality has a significant influence towards purchase intention via mobile app.

H4: System Quality has a significant influence towards purchase intention via mobile app.

H5: Service Quality has a significant influence towards purchase intention via mobile app.

\section{Theoretical Framework}

According to Sekaran \& Bougie (2009), theoretical framework is the basic foundation on which it is coherently created, depicted and 
explained the system of relationship among the variables consider in a specified way that relevant to the problem situation and indicated through the processes of interviews, observations and literature review. The focus of this study is to investigate and examine the relationships between ease of use, usefulness, system quality, information quality, and service quality in the mobile apps towards the consumers purchase intention in Indonesia and Singapore based on the TAM and IS success model. The theoretical framework is shown in Figure 3.

Figure 3. Theoretical Framework

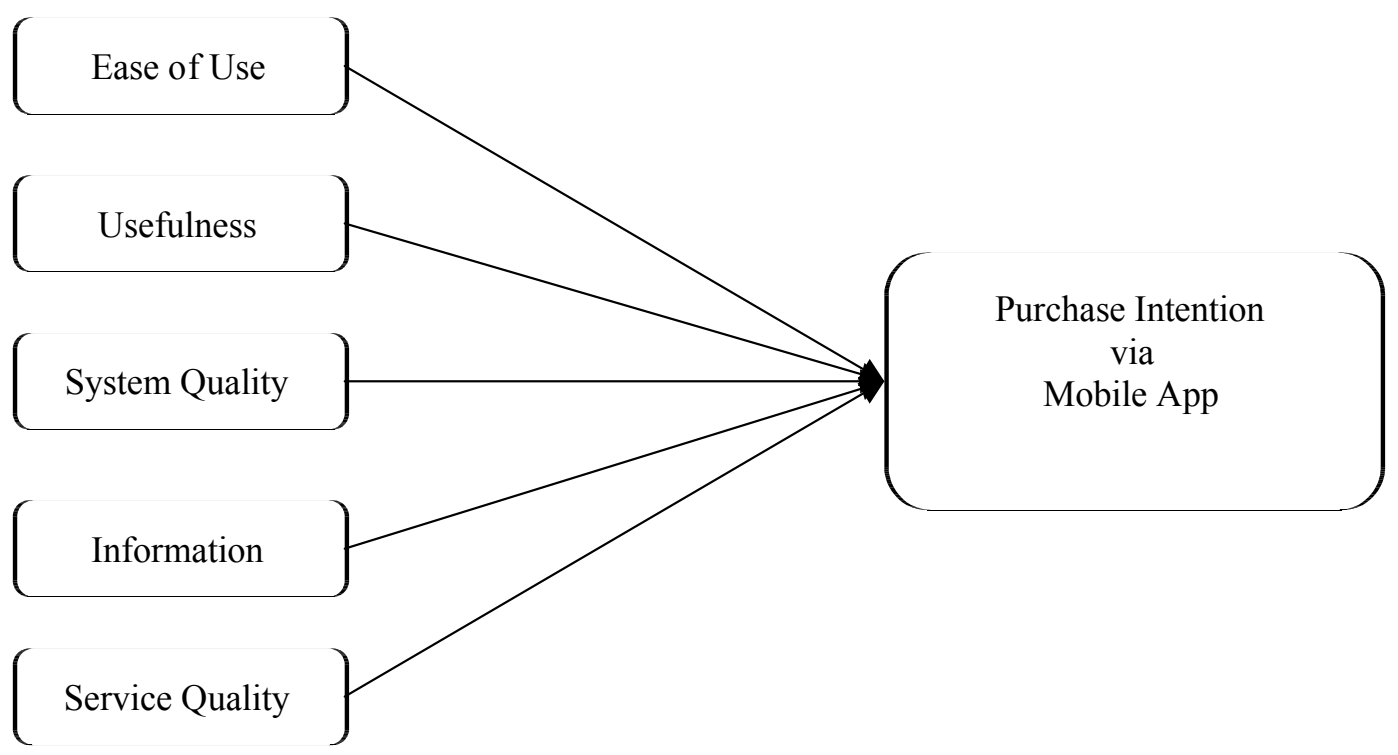

\section{Research methodology}

The methodology section could not be ignored, as it is considered as important section in order to apply a suitable method for achieving the research objective. Furthermore, the significance of using the correct method also generates a more accurate result (Silverman, 1993). 
Therefore, this research has been taken towards selecting an appropriate approach in regard to the research questions that will be used.

\section{Elements of Research Design}

The research design methods/strategies that utilized in this research is the quantitative research. The focus of this method is on the fresh data collection that related to the problem which came from the large population and analysis of the data by neglecting the individual's emotions and feelings or environmental context. The quantitative strategy worked on the objective and measures it through the actions and opinions which helped the researchers to describe the data rather to interpret the data. Besides, this research included for the most part organized inquiries which has foreordained and required an expansive number of respondents to be included.

\section{Statistical Analysis}

The purpose of this research is to find the characteristics of the data and test the hypotheses development for the research. Statistical Package for Social Science (SPSS) is used to conduct the statistical analysis in this research. The statistical analysis tools that will be used are Descriptive Statistic Analysis, Cronbach's Alpha analysis, Coefficients Correlation by Pearson's,, and Multiple Regression Analysis.

Descriptive Statistics Analysis is used to describe the basic features of the data by providing the simple summaries about the sample and the measures to form the basis of virtually every quantitative analysis of data. Pearson Correlation Coefficients, will be used to verify the correlation among variables, and also to measure the significant relationship between it. The Cronbach's Alpha analysis that being used to make sure the consistency of each data which is the reliability analysis. Furthermore, Multiple Linear Regression Analysis is used to 
determine the hypotheses and linear relationship between predetermined variables.

\section{Data collection technique}

This study uses a survey of buyers who use cellphones in order to collect the data that will be used for testing hypotheses and implementing the objectives of this study. Before the survey is conducted, it is important to determine and consider the sample size to be examined. Stevens (2002) argues that in social science research, the number of samples used must be greater than 15 times the number of predictors. Therefore, this study is using 100 sample sizes that collected over the online questionnaire.

\section{Sampling Method and Process}

The target population for doing this research is the consumers of ecommerce in Indonesia and Singapore who had been purchased online via mobile app in the past 6 months. This research accordingly used the simple random sampling to cover the entire population and reduce bias of the data processing.

\section{Administered Survey Design}

Pinsonneault and Kraemer have expressed there are three principle destinations for conducting research with survey questionnaire when: 1) Data of the exploration depends on quantitative strategies/methods, 2) Instruments are utilized in research must be predefined, 3) Research work that requires to dissect finding of an example to entire population. This research used self-administered survey to gather the information/data. Questionnaires are spreaded arbitrarily through online web survey to reach the extensive audience. 


\section{Development of Questionnaire}

The questionnaire consisted of three parts. The first part asks the respondents about their demography. The second part asks about their mobile shopping experiences in the past 6 months. If the respondents don't have mobile shopping activity then they excluded and redirected to different page and the last part asks more details about the dependent and independent variables that will be tested in this research. 5 point Likert scale will be used for the measurement $(1=$ = strongly disagree, $5=$ strongly agree).

All questions are adopted from the existing literature and adjusted for this research.

Table 2. Indicators and points to be evaluated

\begin{tabular}{|c|c|c|}
\hline Indicators & Points to be Evaluated & Adapted from \\
\hline \multirow[t]{4}{*}{ Perceived Ease of Use } & Mobile app is easy to be use & $\begin{array}{l}\text { (Gefen, 2000; Gefen et } \\
\text { al., 2003; Pavlou, 2003) }\end{array}$ \\
\hline & To learn how to operate mobile app is very easy & \multirow{2}{*}{$\begin{array}{l}\text { (Gefen, 2000; Gefen et } \\
\text { al., 2003) } \\
\text { (Gefen, 2000; Gefen et } \\
\text { al., 2003; Pavlou, 2003) }\end{array}$} \\
\hline & $\begin{array}{l}\text { The interaction with the mobile app is very simple and } \\
\text { easy to be understood }\end{array}$ & \\
\hline & It is very easy to get the mobile app to do what you want & $\begin{array}{l}\text { (Heijden et al., 2003; } \\
\text { Venkatesh, 2000) }\end{array}$ \\
\hline \multirow[t]{4}{*}{ Perceived Usefulness } & It is very easy to purchase online by using the mobile app & $\begin{array}{l}\text { (Gefen, 2000; Gefen et al., } \\
\text { 2003; Heijden et al., 2003) }\end{array}$ \\
\hline & It is very fast to purchase online using mobile app & $\begin{array}{l}\text { (Gefen, 2000; Gefen et al., } \\
\text { 2003; Venkatesh., 2003) }\end{array}$ \\
\hline & $\begin{array}{l}\text { The mobile app helps you to improve performance, } \\
\text { effectiveness, productivity in terms of searching as well } \\
\text { as buying the products that you wanted to purchase }\end{array}$ & $\begin{array}{l}\text { (Gefen, 2000; Gefen et al., } \\
\text { 2003; Venkatesh., 2003) }\end{array}$ \\
\hline & $\begin{array}{l}\text { The information provided on mobile app is very useful } \\
\text { for you }\end{array}$ & $\begin{array}{l}\text { (Pavlou, 2003; Heijden et } \\
\text { al., 2003; Venkatesh, 2000) }\end{array}$ \\
\hline \multirow[t]{4}{*}{ System Quality } & The mobile app loads all the texts and graphics that you need & \multirow{4}{*}{$\begin{array}{l}\text { (McKinney et al., 2002; } \\
\text { Kim et al., 2004; Kim et } \\
\text { al., 2010) }\end{array}$} \\
\hline & $\begin{array}{l}\text { The mobile app system is reliable and having a fast response } \\
\text { system }\end{array}$ & \\
\hline & $\begin{array}{l}\text { The mobile app is well-designed and visually interactive } \\
\text { for you }\end{array}$ & \\
\hline & $\begin{array}{l}\text { The mobile app is responsive to your requests and able } \\
\text { to conduct purchase at anytime, from anywhere }\end{array}$ & \\
\hline
\end{tabular}


Cont. table 2

\begin{tabular}{|c|c|c|}
\hline Indicators & Points to be Evaluated & Adapted from \\
\hline \multirow[t]{4}{*}{ Information Quality } & $\begin{array}{l}\text { The mobile app provides relevant information } \\
\text { about the products that you want to buy }\end{array}$ & \multirow{4}{*}{$\begin{array}{l}\text { (McKinney et al., 2002; } \\
\text { Kim et al., 2004) }\end{array}$} \\
\hline & The mobile app provides helpful and credible information & \\
\hline & The mobile app provides high-quality information & \\
\hline & The mobile app provides up-to-date information & \\
\hline \multirow[t]{4}{*}{ Service Quality } & The mobile app provides you the on time services & \multirow{4}{*}{$\begin{array}{l}\text { (McKinney et al., 2002; } \\
\text { Kim et al., 2004) }\end{array}$} \\
\hline & $\begin{array}{l}\text { The mobile app provides you the prompt response } \\
\text { to your inquiries }\end{array}$ & \\
\hline & The mobile app provides you the professional services & \\
\hline & The mobile app provides you the personalized services & \\
\hline Indicators & Points to be Evaluated & Adapted from \\
\hline \multirow[t]{4}{*}{ Purchase Intention } & $\begin{array}{l}\text { I am probably going to purchase products on e-commerce } \\
\text { via mobile app }\end{array}$ & $\begin{array}{l}\text { (Heijden et al., 2003; Chen } \\
\text { and Barn., 2007; Kim et } \\
\text { al., 2008; Ko et al., 2009) }\end{array}$ \\
\hline & $\begin{array}{l}\text { I am probably going to keep purchasing products } \\
\text { on e-commerce via mobile app }\end{array}$ & \multirow[t]{2}{*}{$\begin{array}{l}\text { (Heijden et al, 2003; Chen } \\
\text { and Barn, , 2007; Kim eten al, } \\
\text { 2000; Deha, Lu \& Zhou, } \\
\text { 2008; Ko ut al., 2009) }\end{array}$} \\
\hline & $\begin{array}{l}\text { I would use my credit card to purchase products } \\
\text { on e-commerce via mobile app }\end{array}$ & \\
\hline & $\begin{array}{l}\text { I would not hesitate to provide my personal information } \\
\text { to e-commerce using mobile app as needed to better } \\
\text { fulfill my needs }\end{array}$ & $\begin{array}{l}\text { (Gefen, 2000; Gefen et } \\
\text { al., 2003) }\end{array}$ \\
\hline
\end{tabular}

\section{Reasearch results}

\section{Indonesia Market}

A total of 100 responses were collected which $55 \%$ were male and $45 \%$ were female. Majority of the respondents were between 25 to 35 (65\%). Most of the respondents (72\%) were using mobile application when it is needed only. Top 3 the latest mobile apps downloaded were Tokopedia 1(15\%), Grab (15\%), and Shopee (12\%). More details about the demographics are presented in Table 3. 
Table 3. Demographic characteristics of Indonesian respondents

\begin{tabular}{|c|c|c|c|}
\hline Samples Characteristics & Item & Frequency & Percent \\
\hline \multicolumn{4}{|l|}{ Gender } \\
\hline & Male & 55 & $55 \%$ \\
\hline & Female & 45 & $45 \%$ \\
\hline \multirow[t]{5}{*}{ Age } & & & \\
\hline & $<25$ & 25 & $25 \%$ \\
\hline & $25-35$ & 65 & $65 \%$ \\
\hline & $35-45$ & 10 & $10 \%$ \\
\hline & $>45$ & 0 & $0 \%$ \\
\hline \multirow[t]{5}{*}{ Frequent Using Mobile Apps } & If & 70 & $70 \%$ \\
\hline & Once a week & 7 & $\begin{array}{r}72 \% \\
\end{array}$ \\
\hline & Once a month & 19 & $19 \%$ \\
\hline & Once in 3 months & 1 & $1 \%$ \\
\hline & Once in 6 months & 1 & $1 \%$ \\
\hline \multirow[t]{21}{*}{ Mobile Apps } & & & \\
\hline & Agoda & 1 & $1 \%$ \\
\hline & Booking & 1 & $1 \%$ \\
\hline & Gojek & 7 & $6 \%$ \\
\hline & Lazada & 11 & $9 \%$ \\
\hline & Tokopedia & 17 & $15 \%$ \\
\hline & Shopee & 14 & $12 \%$ \\
\hline & Aliexpress & 2 & $2 \%$ \\
\hline & Bukalapak & 8 & $7 \%$ \\
\hline & Lazada & 8 & $7 \%$ \\
\hline & Traveloka & 3 & $3 \%$ \\
\hline & Bhinneka & 1 & $1 \%$ \\
\hline & Blibli & 9 & $8 \%$ \\
\hline & Ebay & 1 & $1 \%$ \\
\hline & Zalora & 10 & $9 \%$ \\
\hline & JD. ID & 3 & $3 \%$ \\
\hline & Amazon & 1 & $1 \%$ \\
\hline & Eleven Street & 1 & $1 \%$ \\
\hline & Grab & 17 & $15 \%$ \\
\hline & Happy Fresh & 1 & $1 \%$ \\
\hline & Sayurbox & 1 & $1 \%$ \\
\hline
\end{tabular}

Pearson correlation coefficient analysis is utilized to decide the connection between variables/factors. As appeared in the table 4, the correlation coefficient extend from 0.832 to 0.870 . In the meantime, the 
coefficient of Cronbach's Alpha is utilized to evaluate the dependability and consistency of the questionnaire. The dependability scores as appeared in the table 5 ranging from 0.847 to 0.920 which is all variables/factors surpass the dependability scores 0.7 and can be expressed solid (Sekaran and Bougie, 2016). In light of the consequences of multiple regression analysis as appeared in the Table 6, Perceived Usefulness $(\mathrm{P}=0.041, \mathrm{~B}=$ 0.277, $\mathrm{t}=2.071$ ) significantly affects Mobile Purchase Intention in Indonesia (hypothesis 2 supported). Furthermore, the outcomes demonstrated that Information Quality $(\mathrm{P}=0.028, \mathrm{~B}=0.307, \mathrm{t}=2.239)$ significantly affects Mobile Purchase Intention (hypothesis 4 supported).

Table 4. Correlation of Pearson of all variables (Indonesia)

\begin{tabular}{|c|c|c|c|c|c|c|c|}
\hline & & PEOU & PUF & SYQ & IQ & SVQ & MPI \\
\hline PEOU & $\begin{array}{l}\text { Pearson Correlation } \\
\text { Sig. (2-tailed) } \\
\mathrm{N}\end{array}$ & $\begin{array}{c}1 \\
100\end{array}$ & $\begin{array}{c}.887^{* *} \\
.000 \\
100\end{array}$ & $\begin{array}{l}.898^{* *} \\
.000 \\
100\end{array}$ & $\begin{array}{l}.855^{* *} \\
.000 \\
100\end{array}$ & $\begin{array}{c}.877^{* *} \\
.000 \\
100\end{array}$ & $\begin{array}{c}.832^{* *} \\
.000 \\
100\end{array}$ \\
\hline PUF & $\begin{array}{l}\text { Pearson Correlation } \\
\text { Sig. (2-tailed) } \\
\mathrm{N}\end{array}$ & $\begin{array}{l}.887^{* *} \\
100\end{array}$ & $\begin{array}{c}1 \\
.000 \\
100\end{array}$ & $\begin{array}{l}.920^{* *} \\
.000 \\
100\end{array}$ & $\begin{array}{l}.898^{* *} \\
.000 \\
100\end{array}$ & $\begin{array}{l}.909 * * \\
.000 \\
100\end{array}$ & $\begin{array}{c}.870^{* *} \\
.000 \\
100\end{array}$ \\
\hline SYQ & $\begin{array}{l}\text { Pearson Correlation } \\
\text { Sig. (2-tailed) } \\
\mathrm{N}\end{array}$ & $\begin{array}{l}.898^{* *} \\
100\end{array}$ & $\begin{array}{l}.920 * * \\
.000 \\
100\end{array}$ & $\begin{array}{c}1 \\
.000 \\
100\end{array}$ & $\begin{array}{l}.868^{* *} \\
.000 \\
100\end{array}$ & $\begin{array}{l}.898^{* *} \\
.000 \\
100\end{array}$ & $\begin{array}{c}.847^{* *} \\
.000 \\
100\end{array}$ \\
\hline $\mathrm{IQ}$ & $\begin{array}{l}\text { Pearson Correlation } \\
\text { Sig. (2-tailed) } \\
\mathrm{N}\end{array}$ & $\begin{array}{c}.855^{* *} \\
100\end{array}$ & $\begin{array}{l}.898^{* *} \\
.000 \\
100\end{array}$ & $\begin{array}{c}.868^{* *} \\
.000 \\
100\end{array}$ & $\begin{array}{c}1 \\
.000 \\
100\end{array}$ & $\begin{array}{l}.920 * * \\
.000 \\
100\end{array}$ & $\begin{array}{c}.860 * * \\
.000 \\
100\end{array}$ \\
\hline SVQ & $\begin{array}{l}\text { Pearson Correlation } \\
\text { Sig. (2-tailed) } \\
\mathrm{N}\end{array}$ & $\begin{array}{l}.877^{* *} \\
100\end{array}$ & $\begin{array}{l}.909 * * \\
.000 \\
100\end{array}$ & $\begin{array}{c}.898^{* *} \\
.000 \\
100\end{array}$ & $\begin{array}{l}.920 * * \\
.000 \\
100\end{array}$ & $\begin{array}{c}1 \\
.000 \\
100\end{array}$ & $\begin{array}{c}.855^{* *} \\
.000 \\
100\end{array}$ \\
\hline MPI & $\begin{array}{l}\text { Pearson Correlation } \\
\text { Sig. (2-tailed) } \\
\mathrm{N}\end{array}$ & $\begin{array}{c}.832^{* *} \\
100\end{array}$ & $\begin{array}{c}.870^{* * *} \\
.000 \\
100\end{array}$ & $\begin{array}{c}.847^{* *} \\
.000 \\
100\end{array}$ & $\begin{array}{c}.860^{* *} \\
.000 \\
100\end{array}$ & $\begin{array}{c}.855^{* *} \\
.000 \\
100\end{array}$ & $\begin{array}{c}1 \\
.000 \\
100\end{array}$ \\
\hline
\end{tabular}

Indications:

PEOU - Perceived Ease of Use

PUF - Perceived Usefulness

SYQ — System Quality

IQ - Information Quality

SVQ - Service Quality

MPI - Mobile Purchase Intention

**. Correlation is significant at the 0.01 level (2-tailed). 
Table 5. Results of Reliability Coefficient Cronbach's Alpha of all variables (Indonesia)

\begin{tabular}{l|c|c|c}
\hline \multicolumn{1}{c|}{ Variable } & Number of Item & Cronbach's Alpha & Results \\
\hline Perceived Ease of Use (PEOU) & 4 & .922 & Reliable \\
Perceived Usefulness (PF) & 4 & .907 & Reliable \\
System Quality (SYQ) & 4 & .920 & Reliable \\
Information Quality (IQ) & 4 & .874 & Reliable \\
Service Quality (SVQ) & 4 & .910 & Reliable \\
Mobile Purchase Intention (MPI) & 4 & .847 & Reliable \\
\hline
\end{tabular}

Table 6. Results of multiple regression analysis for all variables (Indonesia)

\begin{tabular}{|c|c|c|c|c|c|c|}
\hline & \multirow[t]{2}{*}{ Model } & \multicolumn{2}{|c|}{$\begin{array}{l}\text { Unstandardized } \\
\text { coefficients }\end{array}$} & \multirow{2}{*}{$\begin{array}{c}\begin{array}{c}\text { Standardized } \\
\text { coefficients }\end{array} \\
\text { Beta }\end{array}$} & \multirow[t]{2}{*}{$\mathbf{t}$} & \multirow[t]{2}{*}{ Sig. } \\
\hline & & B & Std. Error & & & \\
\hline \multirow[t]{6}{*}{1} & (Constant) & 1.068 & .777 & 1 & .373 & .173 \\
\hline & PEOU & .113 & .105 & .124 & 1.067 & .288 \\
\hline & PUF & .277 & .134 & .297 & 2.071 & .041 \\
\hline & SYQ & .112 & .131 & .118 & .859 & .393 \\
\hline & IQ & .307 & .137 & .287 & 2.239 & .028 \\
\hline & SVQ & .103 & .136 & .108 & .757 & .451 \\
\hline
\end{tabular}

Indications:

PEOU - Perceived Ease of Use

PUF - Perceived Usefulness

SYQ — System Quality

IQ - Information Quality

SVQ - Service Quality

MPI — Mobile Purchase Intention

a. Dependent Variable: MPI

Notes: R-Square $=0.800$, Adj R-Square $=0.789, \mathrm{~F}=75.029, \mathrm{P}=0.000$

\section{Singapore Market}

In Singapore, the data were collected from 100 respondents in total. From 100 respondents, $49 \%$ of them were men and $51 \%$ of them were women. Also the majority of respondents were between 25 to 35 years. Pretty similar to 
Indonesia where they were using mobile application if it is needed only. The top 3 latest downloaded app were Lazada (8\%), Deliveroo (7\%), and Redmart (6\%).

Table 7. Demographic characteristics of Singaporean respondents

\begin{tabular}{|c|c|c|c|}
\hline Samples Characteristics & Item & Frequency & Percent \\
\hline \multicolumn{4}{|l|}{ Gender } \\
\hline & Male & 49 & $49 \%$ \\
\hline & Female & 51 & $51 \%$ \\
\hline \multicolumn{4}{|l|}{ Age } \\
\hline & $<25$ & 15 & $15 \%$ \\
\hline & $25-35$ & 56 & $56 \%$ \\
\hline & $36-45$ & 21 & $21 \%$ \\
\hline & $>45$ & 8 & $8 \%$ \\
\hline \multicolumn{4}{|l|}{ Frequent Using Mobile Apps } \\
\hline & If needed only & 74 & $74 \%$ \\
\hline & Once a week & 13 & $13 \%$ \\
\hline & Once a month & 11 & $11 \%$ \\
\hline & Once in 3 months & 2 & $2 \%$ \\
\hline & Once in 6 months & 0 & $0 \%$ \\
\hline \multicolumn{4}{|l|}{ Mobile Apps } \\
\hline & Agoda & 2 & $2 \%$ \\
\hline & Aliexpress & 1 & $1 \%$ \\
\hline & Amazon & 3 & $2 \%$ \\
\hline & Asos & 4 & $3 \%$ \\
\hline & Booking.com & 2 & $2 \%$ \\
\hline & Carousell & 5 & $4 \%$ \\
\hline & Deliveroo & 10 & $8 \%$ \\
\hline & Eatigo & 3 & $2 \%$ \\
\hline & Expedia & 3 & $2 \%$ \\
\hline & EZBuy & 4 & $3 \%$ \\
\hline & Expedia & 3 & $2 \%$ \\
\hline & FairPrice & 2 & $2 \%$ \\
\hline & Fave & 3 & $2 \%$ \\
\hline & Foodpanda & 3 & $2 \%$ \\
\hline & Grab & 2 & $2 \%$ \\
\hline & GrabFood & 1 & $1 \%$ \\
\hline & Guardian & 1 & $1 \%$ \\
\hline & Honestbee & 5 & $4 \%$ \\
\hline & Hotels.com & 1 & $1 \%$ \\
\hline
\end{tabular}


Cont. table 7

\begin{tabular}{|c|c|c|c|}
\hline Samples Characteristics & Item & Frequency & Percent \\
\hline & HotelsCombined & 4 & $3 \%$ \\
\hline & iHerb & 6 & $5 \%$ \\
\hline & Klook & 5 & $4 \%$ \\
\hline & Lazada & 10 & $8 \%$ \\
\hline & Peatix & 1 & $1 \%$ \\
\hline & Plus & 1 & $1 \%$ \\
\hline & Qoo10 & 5 & $4 \%$ \\
\hline & Redmart & 8 & $6 \%$ \\
\hline & Reebonz & 1 & $1 \%$ \\
\hline & Sephora & 4 & $3 \%$ \\
\hline & Shopback & 2 & $2 \%$ \\
\hline & Shopee & 4 & $3 \%$ \\
\hline & Starbucks & 1 & $1 \%$ \\
\hline & Taobao & 4 & $3 \%$ \\
\hline & Traveloka & 2 & $2 \%$ \\
\hline & Trip. com & 1 & $1 \%$ \\
\hline & Trivago & 1 & $1 \%$ \\
\hline & Uniqlo & 2 & $2 \%$ \\
\hline & Watson & 1 & $1 \%$ \\
\hline & Zalora & 7 & $5 \%$ \\
\hline & Agoda & 2 & $2 \%$ \\
\hline & Aliexpress & 1 & $1 \%$ \\
\hline & Amazon & 3 & $2 \%$ \\
\hline
\end{tabular}

Based on Table 8, Pearson Correlation for all variables ranging from 0.344 to 0.784 . While reliability scores based on Cronbach Alpha's exceed 0.7 which is between 0.724 to 0.861 . The results in Table 9 show that Perceived Ease of Use $(\mathrm{P}=0.028, \mathrm{~B}=0.234, \mathrm{t}=2.232)$ has significant effect on Mobile Purchase Intention. Usefulness $(P=0.013$, $\mathrm{B}=0.293, \mathrm{t}=2.519)$ has huge impact on Mobile Purchase Intention and Service Quality $(\mathrm{P}=0.028, \mathrm{~B}=0.234, \mathrm{t}=2.232)$ has significant effect on Mobile Purchase Intention which supporting hypothesis 1, hypothesis 2 , and hypothesis 5 respectively. 
Table 8. Correlation of Pearson of all variables (Singapore)

\begin{tabular}{ll|c|c|c|c|c|c}
\hline & & PEOU & PUF & SYQ & IQ & SVQ & MPI \\
\hline PEOU & Pearson Correlation & 1 & $.751^{* *}$ & .173 & $.354^{* *}$ & $.640^{* *}$ & $.669^{* *}$ \\
& Sig. (2-tailed) & & .000 & .086 & .000 & .000 & .000 \\
& $\mathrm{~N}$ & 100 & 100 & 100 & 100 & 100 & 100 \\
\hline PUF & Pearson Correlation & $.751^{* *}$ & 1 & $.277^{* *}$ & $.614^{* *}$ & $.787^{* *}$ & $.782^{* *}$ \\
& Sig. (2-tailed) & .000 & & .005 & .000 & .000 & .000 \\
& $\mathrm{~N}$ & 100 & 100 & 100 & 100 & 100 & 100 \\
\hline SYQ & Pearson Correlation & .173 & $.277^{* *}$ & 1 & $.271^{* *}$ & $.384^{* *}$ & $.344^{* *}$ \\
& Sig. (2-tailed) & .086 & .005 & & .006 & .000 & .000 \\
& $\mathrm{~N}$ & 100 & 100 & 100 & 100 & 100 & 100 \\
\hline IQ & Pearson Correlation & $.354^{* *}$ & $.614^{* *}$ & $.271^{* *}$ & 1 & $.687^{* *}$ & $.626^{* *}$ \\
& Sig. (2-tailed) & .000 & .000 & .006 & & .000 & .000 \\
& $\mathrm{~N}$ & 100 & 100 & 100 & 100 & 100 & 100 \\
\hline SVQ & Pearson Correlation & $.640^{* *}$ & $.787^{* *}$ & $.384^{* *}$ & $.687^{* *}$ & 1 & $.784^{* *}$ \\
& Sig. (2-tailed) & .000 & .000 & .000 & .000 & & .000 \\
& $\mathrm{~N}$ & 100 & 100 & 100 & 100 & 100 & 100 \\
\hline MPI & Pearson Correlation & $.669^{* *}$ & $.782^{* *}$ & $.344^{* *}$ & $.626^{* *}$ & $.784^{* *}$ & 1 \\
& Sig. (2-tailed) & .000 & .000 & .000 & .000 & .000 & \\
& $\mathrm{~N}$ & 100 & 100 & 100 & 100 & 100 & 100 \\
\hline
\end{tabular}

Indications:

PEOU - Perceived Ease of Use

PUF - Perceived Usefulness

SYQ - System Quality

IQ - Information Quality

SVQ — Service Quality

MPI - Mobile Purchase Intention

**. Correlation is significant at the 0.01 level (2-tailed).

Table 9. Results of Reliability Coefficient of Cronbach's Alpha of all variables (Singapore)

\begin{tabular}{l|c|c|c}
\hline \multicolumn{1}{c|}{ Variable } & Number of Item & Cronbach's Alpha & Results \\
\hline Perceived Ease of Use (PEOU) & 4 & .805 & Reliable \\
Perceived Usefulness (PF) & 4 & .861 & Reliable \\
System Quality (SYQ) & 4 & .844 & Reliable \\
Information Quality (IQ) & 4 & .792 & Reliable \\
Service Quality (SVQ) & 4 & .724 & Reliable \\
Mobile Purchase Intention (MPI) & 4 & .777 & Reliable \\
\hline
\end{tabular}


Table 10. Results of multiple regression analysis for variables (Singapore)

\begin{tabular}{|c|c|c|c|c|c|c|}
\hline & \multirow[t]{2}{*}{ Model } & \multicolumn{2}{|c|}{$\begin{array}{l}\text { Unstandardized } \\
\text { coefficients }\end{array}$} & \multirow{2}{*}{$\begin{array}{c}\begin{array}{c}\text { Standardized } \\
\text { coefficients }\end{array} \\
\text { Std. Error }\end{array}$} & \multirow[t]{2}{*}{$\mathbf{t}$} & \multirow[t]{2}{*}{ Sig. } \\
\hline & & B & Std. Error & & & \\
\hline \multirow[t]{6}{*}{1} & (Constant) & -2.997 & 1.378 & & -2.175 & .032 \\
\hline & PEOU & .234 & .105 & .198 & 2.232 & .028 \\
\hline & PUF & .293 & .116 & .277 & 2.519 & .013 \\
\hline & SYQ & .066 & .054 & .074 & 1.223 & .224 \\
\hline & $\mathrm{IQ}$ & .176 & .090 & .158 & 1.953 & .054 \\
\hline & SVQ & .414 & .144 & .303 & 2.867 & .005 \\
\hline
\end{tabular}

Indications:

PEOU - Perceived Ease of Use

PUF - Perceived Usefulness

SYQ — System Quality

IQ - Information Quality

SVQ - Service Quality

MPI - Mobile Purchase Intention

a. Dependent Variable: MPI

Notes: R-Square $=0.711$, Adj R-Square $=0.695, \mathrm{~F}=46.174, \mathrm{P}=0.000$

\section{Conclusion \& implication}

\section{Conclusion}

Southeast Asia as mobile-first economy indicates a huge opportunity but challenging at the same time. Many companies have shifted their strategy on leveraging mobile technology to gain competitive advantage in the market. However, it is not an easy job although mobile penetration as high as $80 \%$ in some countries but people still prefer desktop as their first choice to do an online purchase. Thus, the purpose of this study is to find the most important factors that influencing people to use their mobile app to purchase online in Indonesia and Singapore. It shows that mobile has become a crucial strategy to gain competitive advantage not only to increase sales but also to expand markets and build high quality interaction between 
consumers and mobile devices by utilizing mobile as their shoppersengagement strategy. The IS success model has been extended to measure the relationship among ease of use, usefulness, system quality, information quality, and service quality towards consumer's behaviour in having online purchase intention via mobile app. Results indicate that, overall, the independent variables have a significant positive influence on online purchase intention via mobile app. The study recommended that the ease of use, usefulness, system quality, information quality, and service quality are imperative precursors for estimating online purchase intention via mobile app.

In Indonesia - the results indicate that information quality and usefulness have a significant impact towards the consumers behaviour in having the online purchase intention. Comprehensive information contains all the relevant product attributes for each unique such as: price, description, images etc. If the attributes are missing from a product data that will be fed to consumers, it will not show the complete product information to the consumers. Eventually, if this happens, the retailers lose credibility with the consumers as well as value, because their products is not well described on the screen of the smartphone. By having high-quality of information, the consumers will accordingly easy to understand or stay in contact with the retailers through their unique mobile app. In addition, by having good information quality is the customers will be having the privilege from ease of use to explore everything about the desired products. Consumers are now learning to expect personalization and customization as part of their experience with their retailers. If the retailers can not deliver that type of elevated experience, they are likely to turn to other retailers. Utilizing a good information can also improve the customer experience in using the mobile app that being offered by the retailers in order to have higher purchase intention from the consumers. The improvement of the performance, effectiveness, productivity in terms of searching as well as buying the desired products and the usefulness from the provided information on the mobile app will be targeting the satisfaction of the consumers in order to do the purchase of the desired products through the mobile app. Furthermore, if the mobile app could offer the easy access to be used 
and deliver nice and easy experiences in doing the online purchase through the mobile app, it indicates that perceived usefulness of the mobile app has a significant influence towards purchase intention via mobile app.

In Singapore - the results indicate that ease of use, usefulness, and service quality have a significant impact towards the consumers behaviour in having the online purchase intention. Perceived ease of use: mobile app is easy to be use; to learn how to operate mobile app is very easy; the interaction with the mobile app is very simple and easy to be understood; it is very easy to get the mobile app to do what you want; have delivered the value of 0.028 which indicating that Singaporeans are more concerned on the ease of use from a mobile app. The easier usage of a mobile app will give significant influence towards purchase intention via mobile app.

Perceived ease of use is supported as well by the perceived usefulness that give the best online shopping experiences to the customers which accordingly giving a significant influence towards purchase intention via mobile app. Customer service isn't just about being courteous to consumers. It's a lethal element of business operations that can give the implication to the bottom line and accordingly will affect on how a company is valued and judged from the public point of view. Several outstanding companies have been in the news of late to find themselves in the spotlight because of the bad customer service policies. However, there is good news which is relatively simple to deploy a customer service improvement plan that will keep the business on top. Therefore, the perceived service quality in providing on time services, prompt response to consumers' requires, personalized services, and professional service are also giving the significant impact to online purchase intention from the consumers.

\section{Implication}

It can't be denied the acceptance of online shopping is growing faster over time and play an important role in changing users buying 
behaviour. A lot of companies have tried different strategy to capture the market acceptance especially on mobile strategy because of high penetration in Asia. However, they are also facing many challenges which accordingly cause the purchase intention way lower than on desktop. The study has identified the most important variables that can affect users purchase intention on mobile. The study shows that the eagerness to purchase from desktop is still higher compared to the mobile app because most users still use mobile as the first step in order to find and compare the products that they will buy, which then they will purchase the desired product in-store or via desktop or laptop if they want to buy the desired products online which impacting the growth of online purchase via mobile app is not reflecting the same growth just like the growth of internet mobile usage in Indonesia and Singapore.

Both countries, Indonesia and Singapore, give the different signals of the independent variables that cause the influence the online purchase intention via mobile app. In Indonesia, the factors of information quality and usefulness are dominating the online purchase intention via mobile app. On the other hand, in Singapore, the factor of ease of use, usefulness, and service quality are dominating the online purchase intention via mobile app.

The factor of ease of use, usefulness, service quality, and information quality are accordingly influencing the online purchase intention via mobile app of the consumers. These phenomena will directly give the implication towards the consumer's behaviour in doing the online purchase. There are a lot of factors influencing online purchase intention in researches. Even the factors in different researches can be consistent, the model of factors influencing online shoppers' buying intention can be upgraded and enriched to be much more useful for helping and guiding the management of applications.

\section{Bibliography}

1. Ahmad, Z., \& Ibrahim, R. (2017). Mobile Commerce (M-Commerce) Interface Design: A Review of Literature. 
2. Ajzen, I., (1991). The Theory of Planned Behavior. Organizational Behavior and Human Decision Processes, 179-211.

3. Better Than Cash Alliance. (2017). Social Networks, e-Commerce Platforms, and the Growth of Digital Payment Ecosystems in China: What It Means for Other Countries. Retrieved June 02, 2018, from https://btca-prod.s3.amazonaws.com/documents/ 283/english_attachments/Better_Than_Cash_Alliance_China_Report_April_2017_(1).pd f?1492605583

4. Chen, Y.H. and Barns, S. (2007) 'Initial trust and online behaviour', Industrial Management and Data Systems, Vol. 107, No. 1, pp.21-36.

5. Chen, L.Y. (2013). The Quality of Mobile Shopping System and Its Impact on Purchase Intention and Performance.

6. Chen, M.Y., \& Ching, I.T. (2013). A comprehensive model of the effects of online store image on purchase intention in an e-commerce environment. Electronic Commerce Research, 13(1), 1-23.

7. Dachyar, M., Banjarnahor, L. (2017). Factors influencing purchase intention towards consumer-to-consumer e-commerce.

8. Davis, F.D. (1989). Perceived Usefulness, perceived ease of use, and user acceptance of information technology. MIS Quarterly, 13(3), 319-339

9. Davis, F.D., Bagozzi, R.P., \& Warshaw, P.R. (1989). User acceptance of computer technology: a comparison of two theoretical model. Management Science, Vol. 35, pp. 982-1003.

10. Dehua, H., Lu, Y., \& Zhou, D. (2008). Empirical Study of Customers' Purchase Intention in C2C Ecommerce. Tsinghua Science and Technology, 13(3), 287-292.

11. DeLone, W and E McLean. (2003). The DeLone and McLean model of information system success: a ten-year update. Journal of Management Information System, 19(4), 9-30.

12. eMarketer. (2016). Mobile and Internet Usage Propels Southeast Asia's Retail Ecommerce Sector. Retrieved June 02, 2018, from https://www.emarketer.com/Article/ Mobile-Internet-Usage-Propels-Southeast-Asias-Retail-Ecommerce-Sector/1014431

13. Eom, S. (2013). Testing the Seddon Model of Information System Success in an ELearning Context: Implications for Evaluating DSS. In J. E. Herna'ndez, S. Liu,B. Delibasiic, P. Zarate', F. Dargam, \& R. Ribeiro, Decision Support Systems II - Recent Developments Applied to DSS Network Environments (pp. 19-23). Berlin: SpringerVerlag Berlin Heidelberg.

14. Frost \& Sullivan. (2016). Southeast Asia's E-Commerce market to surpass US\$25 billion by 2020 despite market challenges, finds Frost \& Sullivan. Retrieved June 02, 2018, from https:/ww2.frost.com/news/press-releases/southeast-asias-e-commerce-market-surpassus25-billion-2020-despite-market-challenges-finds-frost-sullivan/

15. Gefen, D. (2000). E-commerce: The Role of Familiarity and Trust. The International Journal of Management Science, 28, 725-737

16. Gefen, D., Karahanna, E., \& Straub, D.W. (2003). Trust and TAM in Online Shopping: An Integrated Model. Management Information System, 27(1), 51-90

17. Google. (2016). Micro-Moments: Your Guide to Winning the Shift to Mobile. Retrieved June 02, 2018, from https://www.thinkwithgoogle.com/marketing-resources/micromoments/micromoments-guide/ 
18. Google. (2017). e-Conomy SEA Spotlight 2017: Unprecedented Growth for Southeast Asia's $\$ 50 B$ Internet Economy. Retrieved June 02, 2018, from https://www.thinkwithgoogle.com/intl/en-apac/tools-research/research-studies/e-conomysea-spotlight-2017-unprecedented-growth-southeast-asia-50-billion-internet-economy/

19. Herzenstein, M., Posavac, S. S., and Brakus, J. (2007). "Adoption of new and really new products: the effects of self-regulation systems and risk salience", Journal of Marketing Research, Vol. 44 No. 2, pp. 251-260.

20. Heijden, H.V., Verhagen, T., \& Creemers, M. (2003). Understanding online purchase intentions: Contributions from technology and trust perspectives. European Journal of Information System, 12, 41-48.

21. Henderson, R., \& Divett, M. J. (2003). Perceived usefulness, ease of use and electronic supermarket use. International Journal of Human-Computer Studies, 59, 383-395.

22. Ho, L. A., Kuo, T. H., and Lin, B. (2012). "The mediating effect of website quality on internet searching behavior", Computers in Human Behavior, Vol. 28 No. 3, pp. 840-848.

23. Iprice insights. (2017). State of eCommerce in Southeast Asia 2017. Retrieved June 02, 2018, from https://iprice.sg/insights/stateofecommerce2017/

24. Ko, E., Kim, E. Y. and Lee, E. K. (2009). "Modelling consumer adoption of mobile shopping for fashion products in Korea", Psychology \& Marketing, Vol. 26, No. 7, pp. 669-687.

25. Kim, J. K., Hong, S., Min, J., and Lee, H. (2011). "Antecedents of application service continuance: a synthesis of satisfaction and trust", Expert Systems with applications, Vol. 38, No.8, pp. 9530-9542.

26. Kim, H.-W., Xu, Y., \& Koh, J. (2004). A comparison of online trust building factors between potential customers and repeat customers. Journal of the Association for Information Systems, 5(10), 392-420.

27. Kim, D. J., Ferrin, D. L., \& Rao, H. R. (2008). A trust-based consumer decision-making model in electronic commerce: The role of trust, perceived risk, and their antecedents. Decision Support Systems, 44(2), 544-564.

28. Lee, H., Fiore, A. M., \& Kim, J. (2006). The role of the Technology Acceptance Model in explaining effects of image interactivity technology on consumer responses. International Journal of Retail \& Management, 34(8), 621-644.

29. Lin, C. C., Wu, H. Y., and Chang, Y. F. (2011). "The critical factors impact on online customer satisfaction", Procedia Computer Science, Vol. 3, No. 1, pp. 276-281.

30. Ling, K. C., Daud, D. B., Piew, T. H., Keoy, K. H., Hassan, P. (2011). Perceived Risk, Perceived Technology, Online Trust for the Online Purchase Intention in Malaysia.

31. Molla, A., and Licker, P. S. (2001). E-Commerce system success:An attempt to extend and respecify the Delone and Mclean model of success. Journal of Electronic Commerce research, 2(4), 131-41.

32. McKinney, V., Yoon, K., Zahedi, F. M. (2002). The measurement of Web-customer satisfaction: An expectation and disconfirmation approach. Information Systems Research (13:3), pp. 296-315.

33. Pavlou, P. A. (2003). Consumer acceptance of electronic commerce: Integrating trust and risk with the technology acceptance model. International Journal of Electronic Commerce, 7(3), 69-103

34. Pinsonneault, A., and Kraemer, K. (1993). Survey research methodology in management information systems: an assessment. Journal of Management Information Systems 10, 75-105. 
35. Pitt, Leyland F, Richard T. Watson, and C. Bruce Kavan. (1995). Service Quality: A Measure of Information Systems Effectiveness. MIS Quarterly, 19(2), pp. 173-87.

36. PR Newswire Asia. (2018). Southeast Asia B2C E-Commerce Market expands by $28.5 \%$ in Q4 2017 with Gross Merchandise Value over US\$6 billion, finds Frost \& Sullivan. Retrieved June 02, 2018, from http:/www.asiaone.com/business/southeast-asia-b2cecommerce-market-expands-by-285-in-q4-2017-with-gross-merchandise-value

37. Rahi, S. (2017) Research Design and Methods: A Systematic Review of Research Paradigms, Sampling Issues and Instruments Development. Int J Econ Manag Sci 6: 403. doi: $10.4172 / 2162-6359.1000403$

38. Rai, A., Lang, S.S., and Welker, R.B. (2002). Assessing the validity of IS success models: An empirical test and theoretical analysis. Information system research, 13(1), 50-69.

39. Renko, M., Carsrud, A., and Brännback, M. (2009). "The effect of a market orientation, entrepreneurial orientation, and technological capability on innovativeness: a study of young biotechnology ventures in the United States and in Scandinavia". Journal of Small Business Management, Vol. 47, No. 3, pp. 331-369.

40. Safeena, Rahmath, and Kammani, Abdullah (2013). Conceptualization of electronic government adoption". International Journal of Managing Information Technology, Vol. 5, No. 1, pp. 13-22.

41. Statista. (2018). Conversion rate of online shoppers worldwide as of 1 st quarter 2018, by platform. Retrieved June 02, 2018, from https://www.statista.com/statistics/ 304280/global-online-shopper-conversion-rate-by-platform/

42. Stevens, J. (2002). Applied multivariate statistics for the social sciences (5th ed.). London: Psychology Press.

43. Sekaran, U., \& Bougie, R. (2016). Research Methods for Business, a Skill Building Approach. UK: John Wiley and Sons, Inc.

44. Silverman D. (1993) Interpreting the Qualitative Data: Methods for analyzing talk,text and interaction. London: SAGE.

45. Shah, H., Aziz, A., Jaffari, A. R., Waris, S., Ejaz, W., Fatima, M. and Sherazi., K.(2012). The Impact of Brands on Consumer Purchase Intentions. Asian Journal of Business Management 4(2): 105-110.

46. Statista. (2015). Retail e-commerce market volume in Southeast Asia in 2015 and 2025, by country (in billion U.S. dollars). Retrieved June 02, 2018, from https://www.statista.com/statistics/647645/southeast-asia-ecommerce-market-size-country/

47. Statista. (2016). Retail e-commerce sales in select countries in Southeast Asia in 2016 (in billion U.S. dollars). Retrieved June 02, 2018, from https://www.statista.com/statistics/ 604964/retail-e-commerce-sales-select-countries-asia-pacific/

48. Venkatesh, V. (2000). Determinants of perceived ease of use: Integrating control, intrinsic motivation, and emotion into the technology acceptance model. Information system research, 46(2), 342-365.

49. WeAreSocial. (2018). Digital in 2018 in Southeast Asia. Retrieved June 02, 2018, from https://www.slideshare.net/wearesocial/digital-in-2018-in-south east-asia-part-2southeast-86866464 
Markun Hanjaya, S.T. - He graduated from the Faculty of Science and Technology with an Industrial Engineering Study Program at Pelita Harapan University. At this time, $\mathrm{He}$ serves as a Production Manager at plastic packaging manufacturing company in Indonesia. The work he does, focuses on planning and developing the effectiveness and efficiency of the system.

Kenny, S.Kom. - He graduated from the Faculty of Computer Science at Bina Nusantara University. Currently, he is working as SEM Manager / Digital Media Specialist at Rakuten Asia in Singapore. His main expertise is digital marketing from paid, organic, mobile, social, and display.

Freddy Gunawan, S.S., S.E. - He graduated from the Faculty of Letters of Universitas Sumatera Utara and the Faculty of Economics of Universitas Methodist Indonesia. Currently, he is the Commercial Manager at East Timor Trading, LDA in East Timor. His professional life is linked to sales and marketing and his main professional interest is designing business development strategies. 